\title{
Akademisyenlerin Eleştirel Düşünme Düzeyleri ile Örgütün Etik İklimine İlişkin Algıları Arasındaki İlişkinin İncelenmesi ${ }^{a}$
}

\author{
Ebru Güzel Kuyucu, c, Selhan Özbeyd, R. Timuçin Gençere
}

\section{Özet}

Eleştirel düşünce akademik yaşamın en önemli özelliklerinden birisidir. Bu çalışma, spor bilimleri alanındaki akademisyenlerin eleştirel düşünme düzeyleri ile örgütün etik iklimine ilişkin algıları arasındaki ilişkinin belirlenmesi amacıyla yapılmıştır. Araştırmaya Ege Bölgesi'nde bulunan Spor Bilimleri Fakültelerinde çalışan 130 akademisyen (39 kadın, 91 erkek) katılmıştır. Çalışmada, Kaliforniya Eleştirel Düşünme Eğilimleri Ölçeği (KEDEÖ), Etik İklim Ölçeği (Eİ̈) ve kişisel bilgi formu kullanılmıştır. Akademisyenlerin orta düzeyde eleştirel düşünme düzeyine ( $\bar{X}=241,58$; $\mathrm{Ss}=.16,31)$ sahip oldukları ve çalıştıkları üniversitenin etik iklimine biraz katıldıkları ( $\left.\bar{X}=2.62 ; S_{s}=.46\right)$ görülmüştür. Akademisyenlerin eleştirel düşünce düzeyleri ile etik iklim $(\mathrm{r}=-, 245)$, egoist iklim $(\mathrm{r}=-, 299)$ ve ilkelilik iklimi $(\mathrm{r}=$ ,289) arasında negatif yönde anlamlı ilişkiler olduğu belirlenmiştir. Akademisyenlerin, eleştirel düşünme düzeylerini geliştirebilmesi önemlidir. Bununla beraber bilimsel üretim ve verimlilik için çalışma ortamında yaratılacak olan etik iklim vazgeçilmez bir rol oynar.
Anahtar Kelimeler

Eleştirel Düşünme

Etik İkim

Akademisyenler

Spor Bilimleri

Makale Hakkında

Geliş Tarihi: 22.09.2020

Kabul Tarihi: 25.12.2020

Doi: 10.18026/cbayarsos.798466

\section{Investigation of the Relationship Between Academicians' Critical Thinking Levels and Perceptions of the Organization on Ethical Climate}

\section{Abstract}

Critical thinking is one of the most important features of academic life. The purpose of this study was to determine the relationship between the critical thinking level of academicians in sports sciences research area and their perceptions about the ethical climate of the organization. The total of 130 academicians (39 females \& 91 males) working in the Sports Sciences Faculty in the Aegean Region participated in the study. In this study, California Critical Thinking Dispositions Inventory, Ethical Climate Scale (SES) and a questionnaire form were used to collect data. It was determined that academicians had moderate critical thinking level $(\mathrm{M}=241.58$; $\mathrm{Sd}=.16 .31)$ and they slightly involved in the ethical climate of the university $(\mathrm{M}=2.62$; $\mathrm{Sd}=$ .46). It was found that there was a negative relationship between the critical thinking levels of academicians and ethical climate $(r=-, 245)$, egoist climate $(r$ $=-, 299)$ and primitive climate $(r=-, 289)$. It is important for academics to improve their critical thinking levels. However, the ethical climate to be created in the working environment for scientific production and efficiency plays an indispensable role.
Keywords

Critical Thinking

Ethical Climate

Akademicians

Sport Science

About Article

Received: 22.09.2020

Accepted: 25.12 .2020

Doi: 10.18026/cbayarsos.798466

\footnotetext{
a 13-16 Kasım 2019 tarihlerinde 17. Uluslararası Spor Bilimleri Kongresinde sözel bildiri olarak sunulmuştur.

b İletişim Yazarı: ebruguzel@trabzon.edu.tr

c Arş. Gör, Trabzon Üniversitesi, Spor Bilimleri Fakültesi, 0000-0002-8792-3072.

d Doç. Dr. Manisa Celal Bayar Üniversitesi, Spor Bilimleri Fakültesi, 0000-0003-4844-6338

e Prof. Dr. Ege Üniversitesi, Spor Bilimleri Fakültesi, 0000-0003-0159-2610
} 


\section{Giriş}

Yirmi birinci yüzyılda küreselleşen dünya, hızlı bir değişim göstermeye başlamıştır. Sanayi, bilim, teknoloji gibi birçok alandaki gelişmeler, sosyal, kültürel ve ekonomik alanlarında ülkeleri, kurumları ve toplumları zorunlu bir değişim ve gelişme sürecine sokmuştur. Gelişmiş ve çağdaş ülkeler, yaşanan bu değişimlere ve gelişmelere kolaylıkla uyum sağlayabilirken, gelişmekte olan ve geri kalmış ülkelerdeki bu uyum ve değişim bazı sancılı süreçlere neden olmaktadır. Özellikle 1980'lerden sonra, iletişim teknolojilerinde yaşanan değişimler, ulaşım alanındaki yenilikler ve buna bağlı olarak artan üretim, tüketim ve bilgi ihtiyacı sonucunda, ülkeler arasındaki sınırlar ortadan kalkmaya başlamış ve toplumlararası bilgi alışverişi hızlanmıştır (Burkhart, 2006; Yıldız, Güzel ve Zerengök, 2019; Yıldız, Kurnaz ve Kırık, 2020). Tüm bu gelişmeler dünyanın küçük bir köy olarak algılanmasını sağlamıştır. Buna sebeple bilgi, hızlı bir artış göstererek tüm toplumlar, kültürler tarafından anında paylaşılan, kolayca ulaşılabilir bir veri haline gelmiş ve sonuç olarak oluşan bilgi yoğunluğu, devamında bilgi patlamasını meydana getirmiştir (Polat, 2017:1).

Bireyler, geçmişten günümüze çevresine karşı ilgisiz kalmayıp, çevresinde olup bitenleri büyük bir merakla incelemiştir. Doğası gereği olayları kendine göre şekillendirmeye çalışıp, bulunduğu şartlarla yetinmeyip hep daha iyisinin istemiştir. Tüm bunları yaparken düşünme yetisini en iyi biçimde kullanmaya çalışmıştır. Bu durum insanı diğer canlılardan ayıran en önemli özellik olmuştur (Polat, 2014:2). Bilgi gücünün farkına varılması ile insanları yönlendirmek için kaba kuvvet ve silah kullanımı yerini, bilgiyi etkin ve verimli bir biçimde kullanmaya bırakmıştır (Başar, 2013: 19). Bu nedenle başarılı olabilmek için iş birliği yapmak, paylaşımlar da bulunabilmek, problemler karşısında bilgiyi verimli bir biçimde kullanabilmek, gelişen şartlara uyum sağlayabilmek, teknoloji iyi ve etkin bir biçimde kullanabilmesi gerekmektedir. Geçmiş dönemlerde bireylerden beklenen bilgi, beceriler yerini, çağımızın başlıca zorunluluğu olarak görülen eleştirel düşünme, problem çözme, yaratıcı düşünme, etkili ve verimli iletişim, iş birliği, bilgi paylaşımı, yenilik, becerileri almıştır (Saçlı, 2013: 2). Ayrıca her gün farklılaşan, gelişen bilgi yoğunluğunun, kişilere eğitim aracılığıyla aktarılması ve ezberletilmesi mümkün olmamaktadır. Bu nedenle bilgileri süzgeçten geçirip gerekli olan doğru bilgiyi seçebilmek (Robey, 2002); ve bu bilginin de etkili ve verimli bir biçimde kullanabilmesi için üst seviye düşünme becerilerinin kişilere kazandırılması bir zorunluluk olmuştur (Rucks, 2001; Weinerman, 1997). Yaşadığımız bilgi çağında bilim ve teknolojinin hızlı bir şekilde gelişmesi, giderek kalifiye insan gücüne olan ihtiyacın artmasına neden olmaktadır. Bu durum sayesinde, kişiler kendilerini iyi tanıyabilen, bireysel ve toplumsal gelişimi önemseyen, düşünebilen, sorgulayabilen, araştırmacı, mantıklı kararlar veren ve eleştirel düşünme becerisine sahip bir bireyler olmaktadır (Karagenç, 2003; Akt: Öztürk ve Ulusoy, 2008). Eleştirel düşünmeden kastedilen, bir konu hakkında okunmuş ya da söylenmiş bilgiler ile alakalı net bir sonuca varmaktan ziyade, alternatiflerinde olabileceğini de göz ardı etmemektir (Bulut ve diğerleri, 2009). Eleştirel düşünebilmek ve verimli kararlar alabilmek, eğitimli kişilerde bulunması gereken bilişsel becerilerdir. Sahip olduğumuz ön yargılar, genellemeler, varsayımlar, sabit düşünceler dünyayı ve etrafımızı algılama şeklimizi ve davranışlarımızı etkilemektedir. (Paul, 1984; Akt: Akbıyık ve Seferoğlu, 2002). Mc Bride (1992) spor alanında eğitimsel olarak eleştirel düşünmeyi; bir harekete yönelik koruyucu ve savunmacı akla yatkın kararlar vermek amacıyla yansıtıcı düşünme şekli olarak açıklamıştır. Bu nedenle, harekete bağlı bilişsel etkileşimde bulunabilmek, spor eğitim ve yönetim alanların açısından da eleştirel düşünmenin önemli olduğunu göstermektedir (Mc Bride ve Cleland, 1998: 43). Mc Bride(1992), Tishmann ve Perkins (1995)'e göre eleştirel 
düşünmenin beden eğitimi ve spor alanında kullanılması, detaylı ve kapsamlı düşünme, yeni farklı yöntemler bulma, değerlendirici bir akıl yürütme becerisi ile karşılaştırma yapma, planlı ve stratejik düşünme, üst-biliş becerilerini kullanma ve zorluklar karşısında mantıklı kararlar vermeye olanak sağlamaktadır.

İçinde bulunduğumuz dönemde bilişim ve iletişim teknolojilerinin artılarından biri de, kurumsal seviyede her davranışın dişarıdan izlenebiliyor olmasıdır. Kurumlarda dönem dönem karşılaşılan usulsüz davranışlar, adam kayırma ve adaletsiz olma gibi etik dişı hareketler böyle ortamlarda daha çok dikkat çekmektedir. Bu nedenle, kurumların bu konuda daha duyarlı olmaları gerekmektedir (Dönertaş, 2008). Günümüzde örgütsel başarısının sağlanması amacıyla, etik değerlere uygun etkin bir çalışma ortamının sağlanması gereklidir. Örgüt içerisindeki bireylerin iş tatminlerinin yüksek olması için çalışma ortamı istenilen özelliklerde olması gerekmektedir (Tiryaki ve Bahçecik, 2014). Etik iklim, bir örgütte ahlaki yönden sorun çıkarabilecek konuların çözülebilmesi ve etiğe uygun olan doğru davranış biçiminin belirlenmesine ilişkin bir algı olarak ifade edilmektedir (Erdirençelebi ve Filizöz, 2016:129). Örgütsel etik iklim algılamaları, bireylerin motivasyonları, verimlilikleri ve etkinlikleri için büyük bir önem taşımaktadır. Bu sebeple etik ile ilgili değer ve normları örgüt içerine taşımak için etik iklimin oluşturulması gerekmektedir (Bilgen, 2014). Bu bilgiler doğrultusunda, örgütlerde bireylerin sorumluluklarını yerine getirebilmeleri ve ahlaka uygun davranmalarını sağlamak için, örgütün pozitif bir etik iklim algısına sahip olması gerekmektedir. Bireylerin algıladıkları etik iklim ile çalıştıkları kuruma karşı duymuş oldukları güvenin, bireylerin kurumuna yönelik olan algılarını etkileyecek önemli bir unsur olarak görülmektedir (Dönertaş, 2008). Günümüzde akademisyenler, yaratıcı düşünceler üretebilmeli, kişiliğini geliştirmeli, esnek davranabilmeli, yeniliklere ve gelişmelere kolaylıkla uyum sağlayabilmeli, özetle, modern profesyonel özelliklere sahip olmalıdır. Bu özelliklerin kazanılması öğrencilere yeniliklere ve gelişmelere uyum sağlayabilmeleri için temel esasları özümsetmeyi, eleştirel düşünme gücünü kullanarak problemleri çözümleyebilme niteliği kazandırmayı amaçlayan modern eğitim anlayışı ile mümkün olmaktadır. Modern eğitim anlayışının gerçekleştirilmesinde, evrensel düşünen bireylerin bulunduğu üniversiteler hayati önem taşımaktadır (Kaya, 1997; Kökdemir, 2003a; Kürüm, 2002). Modern eğitim anlayışında mevcut bilgileri sorgulamadan kabul eden bireyler yetiştirmek yerine, neyi, neden, niçin ve nasıl öğrenmesi gerektiğini bilen, öğrendiği bilgileri kullanan, geliştiren ve yeni bilgi üreten kişilerin yetiştirilmesi hedeflenmektedir. Bu sebeple mevcut eğitim sisteminin en önemli görevlerinden biri topluma fayda sağlayacak eleştirel düşünen bireyler kazandırmaktır (Kürüm, 2002).

Beden eğitimi ve spor alanındaki eğitimcilerin de modern değişen yaşam koşullarına ayak uydurabilmesi adına eğitim programlarının düzenlenmesi ve geliştirilmesi gerekmektedir. Geleceğin öğretmen, antrenör ve yönetici adayları olan bireylere eleştirel düşünme becerilerini öğretmede en önemli görev akademisyenlere düşmektedir. Bunun için öncelikle akademisyenlerin eleştirel düşünme becerilerinin belirlenmesi ve eleştirel düşünmeye yönelik bakış açılarının belirlenerek bu konunun öneminin vurgulanması gerektiğine inanılmaktadır. Bununla beraber akademisyenlerin etik iklim algılarının yükselmesi, onların kuruma olan bağlılıklarını, kuruma duydukları güvenlerini, birbirleriyle olan ilişkilerini ve kurum amaçlarını gerçekleştirme yönündeki çalışmaların etkililiğini arttırabileceği düşünülmektedir. Üniversite öğrencilerine, evrensel değerlere açık, toplumun değerleri ile örtüşen, hoşgörülü, özgür düşünebilen, bilimsel ve demokratik düşüncenin kazandırılması için üniversite ortamının bunu sağlayacak özellikte ve nitelikte olması gerekmektedir. Bilimsel ve özgür 
düşünmeyi kendisine amaç olarak gören üniversitelerde eleştirel düşünme önemli rol oynamaktadır. Üniversiteler görev yapan akademisyenler öğrencilerin eleştirel düşünmelerini geliştirmeye olanak sağlayan bir eğitim-öğretim anlayışı sahiplenmeli ve öncelikle eleştirel düşünme becerisine sahip olmaları gerekmektedir. Bununla beraber bilimsel üretim ve verimlilik için çalışma ortamında yaratılacak olan etik iklim vazgeçilmez bir rol oynar. Bu noktadan hareketle; akademisyenlerin eleştirel düşünme düzeyleri ile örgütün etik iklimine ilişkin algıları arasında ilişkinin belirlenmesi bu araştırmanın amacını oluşturmaktadır.

\section{Yöntem}

\section{Araştırma Modeli}

Bu araştırmada, akademisyenlerin eleştirel düşünme düzeylerinin ve örgütün etik iklimine ilişkin algılarının çeşitli demografik faktörler açısından incelemek amacıyla nedenselkarşılaştırma yöntemi kullanılmıştır. Nedensel-karşılaştırma yöntemi; belirli bir değişken açısından farklı olan grupların birbirleriyle karşılaştırmak amacıyla kullanılmaktadır. Akademisyenlerin eleştirel düşünme düzeyleri ile örgütün etik iklimine ilişkin algıları arasındaki ilişkiyi belirlemek amacıyla bağıntısal yöntem kullanılmıştır. Bağıntısal yöntem; iki veya ikiden fazla değişken arasında ilişki olup olmadığını tespit etmek için kullanılan yöntemdir (Gurbetoğlu, 2018:12).

\section{Araştırma Grubu}

Araştırmada Ege bölgesinde bulunan spor bilimleri fakültelerine araştırmanın uygulanması için gerekli izin yazıları gönderilmiş ve örneklem grubu uygulamaya izin veren üniversiteler arasından basit tesadüfi örnekleme yöntemi ile belirlenmiştir. Buradan hareketle araştırmanın evrenini; Ege Bölgesinde bulunan üniversitelerdeki akademisyenler oluştururken, örneklemi ise; Ege Üniversitesi Spor Bilimleri Fakültesi, Manisa Celal Bayar Üniversitesi Spor Bilimleri Fakültesi, Muğla Sıtkı Koçman Üniversitesi Spor Bilimleri Fakültesi, Aydın Adnan Menderes Üniversitesi Spor Bilimleri Fakültesi, Uşak Üniversitesi Spor Bilimleri Fakültelerinde çalışan 39 kadın, 91 erkek toplam 130 akademisyenden oluşmaktadır.

\section{Veri Toplama Araçları}

Kişisel Bilgi Formu: Bu çalışmada akademisyenlerin, kişisel özelliklerini ortaya koymak için araştırmacı tarafından hazırlanan 7 sorudan oluşan kişisel bilgi formu kullanılmıştır. Bu formda akademisyenlerin kişisel özellikleri ile ilgili yaş, cinsiyet, medeni durum, kurumdaki unvan, hizmet süresi, bağlı oldukları kurumda çalışmaya başladıkları yıl, yönetici pozisyonları gibi sorulara yer verilmiştir.

Kaliforniya Eleştirel Düşünme Eğilimleri Ölçeği (KEDEÖ): Araştırmada, akademisyenlerin eleştirel düşünme eğilimlerini ölçmek için, literatürde yaygın olarak kullanılan, ölçeğin orjinali Facione, Facione, ve Giancarlo tarafından 1998 yılında geliştirilen, Türkçeye uyarlaması, geçerlik-güvenirlik çalışması Kökdemir (2003b) tarafından yapılmış olan, Kaliforniya Eleştirel Düşünme Eğilimleri Ölçeğinin kısaltılmış Türkçe versiyonu (KEDEÖ) kullanılmıştır (Kökdemir, 2003:68). Türkçeye uyarlama sonrasında, ölçek 7 faktörden 6 faktöre ve 75 maddeden 51 maddeye düşürülmüştür. Ölçeğin alt boyutları; meraklılık, açık fikirlik, sistematiklik, kendine güven, doğruyu arama, analitiklik' ten oluşmaktadır. Ölçeğin toplam varyansı \%36,13 olarak tespit edilmiş, alt boyutlarının iç tutarlılık katsayıları (alfa) .61 ile.78 arasında değişirken, ölçeğin iç tutarlılık katsayısı (alfa) ise 0,88 olarak belirlenmiştir (Kutlu ve 
Schreglmann, 2011:118). Ölçeğin maddeleri, 6`l1 Likert tipidir hesaplanmasında alınabilecek en yüksek puan 360, en düşük puan ise 60 olarak belirlenmiştir. Bir alt ölçekten 50 puan üstü yüksek eleştirel düşünme eğilimini 40 puan altı düşük eleştirel düşünme eğilimini, göstermektedir. Alt ölçeklerin toplamı ise eleştirel düşünme eğilim puanını vermektedir. KEDEÖ' nün değerlendirilmesinde; 240'dan az puan düşük, 240-300 arasında puan alanların orta 300 puanın üstü yüksek eleştirel düşünme eğilimi sahip olarak belirtilmiştir. Ölçekteki 50, $49,47,45,43,41,36,33,28,27,25,23,22,21,20,19,18,15,11,09,06,05$, numaralı maddeler ters çevrilerek puanlanmaktadır (Balc1, 2015: 78-81).

Etik İklim Ölçeği (EİÖ): Araştırmada, Victor ve Cullen (1993) tarafından geliştirilmiş olan, 36 sorudan oluşan etik iklim ölçeği kullanılmıştır. Ölçeğin Türkçe 'ye çevrilmesi, geçerlilik ve güvenirlilik çalışması Eser (2007) tarafından yapılmış ve güvenilirliği $\alpha:, 9065$ bulunmuştur (Eser, 2007:41-42).

Ölçekteki soruların yardımseverlik iklimi, egoist iklim, ve ilkelilik iklimleri ile ilgili 12 sorudan oluşan 3 alt boyut bulunmaktadır. Ölçeğin;

$5,12,16,21,26,27,28,30,31,32,34$, ve 35. maddeleri yardımseverlik iklim, $1,2,4,6,8,10,17,19,25,29,33$ ve 36 . maddeleri egoist iklim,

$3,7,9,11,13,14,15,18,20,22,23$ ve 24 . maddeleri ise ilkelilik iklim alt boyutu ile alakalıdır.

1,6 ve 10 numaralı sorular ters kodlanır. Ölçek 5'li likert tipidir. Her soru için minimum değer " 1 " ve maksimum değer " 5 "tir. İklim Ölçek değeri her bir kişi için 36 soruya verilen değerlerin toplamının 36'ya bölümüdür. Böylece akademisyenlerin bağlı oldukları üniversitenin etik iklimi ile ilgili puan ortalama değerinin 1'e yaklaşması akademisyenlerin çalıştıkları üniversitenin etik iklimi ile ilgili görüşlere katılmadıklarını, 5'e yaklaşması ise üniversitenin etik iklimini onayladıklarını göstermektedir (Şahin ve Dündar, 2011:137).

\section{Verilerin Analizi}

Elde edilen veriler, SPSS 22.0 paket programı kullanılarak analiz edilmiş, verilerin analizinde normallik testi yapılmış, normal dağılım gösteren verileri için parametrik testler, normal dağılım göstermeyen veriler için nonparametrik testler kullanılmıştır. Değerlendirilme kapsamında yüzde, ortalama, standart sapma gibi tanımlayıcı istatistiksel metotlar kullanılmıştır. Verilerin analizinde $t$ testi, tek yönlü varyans analizi (ANOVA), kruskal-wallis $\mathrm{h}$ testi, mann whitney $\mathrm{u}$ testi, post hoc testi ve korelasyon analizi kullanılmıştır. Analiz sonuçları en az $\mathrm{p}<.05$ güven aralığında değerlendirilmiştir. 
Akademisyenlerin Eleştirel Düşünme Düzeyleri ile Örgütün Etik İklimine İlişkin Algıları Arasında İlişkinin İncelenmesi

\section{Bulgular}

Tablo 1. Katılımcılara İlişkin Kişisel Bilgiler

\begin{tabular}{llcc}
\hline Değişkenler & Gruplar & N & $\%$ \\
\hline Yaş & $25-35$ & 27 & 20,8 \\
& $36-45$ & 60 & 46,2 \\
& 46 ve üzeri & 43 & 33,1 \\
\hline Cinsiyet & Kadın & 39 & 30 \\
& Erkek & 91 & 70 \\
\hline Medeni Durum & Bekar & 40 & 30,8 \\
& Evli & 90 & 69,2 \\
\hline Unvan & Arş. Gör. & 18 & 13,8 \\
& Öğr. Gör. & 26 & 20 \\
& Dr. Öğr. Üyesi & 54 & 41,5 \\
& Doç. Dr. & 23 & 17,7 \\
& Prof. Dr. & 9 & 6,9 \\
\hline Hizmet Süresi & 1-5 yıl & 16 & 12,3 \\
& 6-10 yıl & 20 & 15,4 \\
& 11 yıl ve üzeri & 94 & $\mathbf{7 2 , 3}$ \\
\hline Toplam & & $\mathbf{1 3 0}$ & $\mathbf{1 0 0}$ \\
\hline
\end{tabular}

Tablo 1'de katılımclara ilişkin kişisel bilgiler sunulmuştur. Unvan değişkeni açısından incelendiğinde katılımcıların \%41,5'inin Dr. Öğr. Üyesi olduğu görülmektedir. Hizmet süresi açısından bakıldığında \%72,3’nün 11 yıl ve üzeri çalıştıkları görülmektedir.

Tablo 2. Kaliforniya Eleştirel Düşünme Eğilimleri Ölçeği ve Etik İklim Ölçeğinin Alt Boyutlara İlişkin Ortalama ve Yaygınlık Ölçüleri

\begin{tabular}{lccc}
\hline Ölçek/alt boyut adı & $\mathbf{N}$ & $\overline{\mathbf{x}}$ & ss \\
\hline KEDEÖ & 130 & 241,58 & 16,31 \\
\hline Doğruyu Arama & 130 & 41,46 & 7,32 \\
Açık Fikirlilik & 130 & 46,44 & 6,53 \\
Analitiklik & 130 & 50,99 & 3,48 \\
Sistematiklik & 130 & 47,48 & 7,71 \\
Kendine Güven & 130 & 45,96 & 5,86 \\
Meraklılık & 130 & 50,13 & 4,86 \\
\hline
\end{tabular}




\begin{tabular}{lccc}
\hline Ė̈̈ & 130 & 2,72 & 0,46 \\
\hline Egoist İklim & 130 & 2,77 & 0,4 \\
Yardımsever İklim & 130 & 2,78 & 0,7 \\
İlkelilik İklim & 130 & 2,61 & 0,55 \\
\hline
\end{tabular}

Araştırmaya katılan akademisyenlerin KEDEÖ ait puan ortalamaları $\bar{x}=241,58$, doğruyu arama boyutuna ait puan ortalamaları $\bar{x}=41,46$, açık fikirlilik boyutuna ait puan ortalamaları $\bar{x}=46,44$, analitiklik boyutuna ait puan ortalamaları $\bar{x}=50,99$, sistematiklik boyutuna ait puan ortalamaları $\bar{x}=47,48$, kendine güven boyutuna ait puan ortalamaları $\bar{x}=45,96$, meraklılık boyutuna ait puan ortalamaları $\bar{x}=50,13$ olarak tespit edilmiştir. EïÖ toplamına ait puan ortalamaları $\bar{x}=2,72$, egoist iklim alt boyutuna ait puan ortalamaları $\bar{x}=2,77$, yardımsever iklim alt boyutuna ait puan ortalamaları $\bar{x}=2,78$, ilkelilik iklim alt boyutuna ait puan ortalamaları $\bar{x}=2,61$ olarak tespit edilmiştir.

Tablo 3. Akademisyenlerin KEDEÖ ile Demografik Değişkenlere İlişkin t Testi ve Varyans

\begin{tabular}{|c|c|c|c|c|c|c|}
\hline \multicolumn{7}{|c|}{ Analizleri } \\
\hline Değişken & Grup & $\mathbf{n}$ & $\bar{x}$ & ss & $t$ & $p$ \\
\hline \multirow[t]{2}{*}{ Cinsiyet } & Kadın & 39 & 243,36 & 15 & \multirow{2}{*}{0,814} & \multirow{2}{*}{0,417} \\
\hline & Erkek & 91 & 240,81 & 16,86 & & \\
\hline \multirow[t]{2}{*}{ Medeni Durum } & Bekar & 40 & 244,28 & 12,15 & \multirow{2}{*}{1,452} & \multirow{2}{*}{0,149} \\
\hline & Evli & 90 & 240,38 & 17,78 & & \\
\hline Değişken & Grup & $\mathbf{n}$ & $\bar{x}$ & ss & $\mathrm{f}$ & p \\
\hline \multirow[t]{3}{*}{ Yaş } & $25-35$ & 27 & 244,63 & 11,79 & \multirow{3}{*}{0,599} & \multirow{3}{*}{0,551} \\
\hline & $36-45$ & 60 & 240,63 & 17,48 & & \\
\hline & 46 ve üzeri & 43 & 240,98 & 17,15 & & \\
\hline \multirow[t]{5}{*}{ Unvan } & Arş. Gör. & 18 & 241,61 & 12,68 & \multirow{5}{*}{1,194} & \multirow{5}{*}{0,316} \\
\hline & Öğr. Gör. & 26 & 241,92 & 14,6 & & \\
\hline & Dr. Öğr. Üyesi & 54 & 238,91 & 18,26 & & \\
\hline & Doç. Dr. & 23 & 242,57 & 14,8 & & \\
\hline & Prof. Dr. & 9 & 252,33 & 18,03 & & \\
\hline \multirow[t]{3}{*}{ Hizmet Süresi } & $1-5$ yil & 16 & 247,25 & 12,5 & \multirow{3}{*}{1,33} & \multirow{3}{*}{0,325} \\
\hline & 6-10 yil & 20 & 241,55 & 10,72 & & \\
\hline & 11 yıl ve üzeri & 94 & 240,62 & 17,72 & & \\
\hline
\end{tabular}

\begin{tabular}{ll}
\hline Toplam & 130
\end{tabular}

$\mathrm{p}>0,05$ 
Akademisyenlerin eleştirel düşünme ölçeğinden aldıkları puan ortalamaları cinsiyet, medeni durum, yaş, unvan, hizmet süresi değişkenleri ile karşılaştırıldığında istatistiksel olarak anlamlı bir fark bulunamamıştır (Tablo 3).

Tablo 4. Akademisyenlerin Etik İklim Ölçeği ile Unvan Değişkenine İlişkin Kruskal-Wallis H Testi Sonuçları

\begin{tabular}{|c|c|c|c|c|c|c|}
\hline & Unvan & $\mathbf{n}$ & Sira ort. & $\mathrm{x} 2$ & $\mathrm{p}$ & Fark \\
\hline \multirow{7}{*}{ EİÖ } & Arş. Gör. & 18 & 69,03 & & & \\
\hline & Öğr. Gör. & 26 & 66,31 & & & \\
\hline & Dr. Öğr. Üyesi & 54 & 67,44 & 5,151 & 0,398 & - \\
\hline & Doç. Dr. & 23 & 68,70 & & & \\
\hline & Prof. Dr. & 9 & 38,83 & & & \\
\hline & Arş. Gör. & 18 & 72,25 & & & \\
\hline & Öğr. Gör. & 26 & 53,15 & & & \\
\hline \multirow[t]{5}{*}{ Egoist iklim } & Dr. Öğr. Üyesi & 54 & 71,95 & 12,776 & $0,026^{*}$ & $(4-5)$ \\
\hline & Doç. Dr. & 23 & 72,48 & & & \\
\hline & Prof. Dr. & 9 & 34,89 & & & \\
\hline & Arş. Gör. & 18 & 63,75 & & & \\
\hline & Öğr. Gör. & 26 & 72,21 & & & \\
\hline \multirow[t]{5}{*}{ Yardımsever iklim } & Dr. Öğr. Üyesi & 54 & 64,23 & 5,494 & 0,359 & - \\
\hline & Doç. Dr. & 23 & 72,17 & & & \\
\hline & Prof. Dr. & 9 & 40,78 & & & \\
\hline & Arş. Gör. & 18 & 68,97 & & & \\
\hline & Öğr. Gör. & 26 & 66,96 & & & \\
\hline \multirow[t]{3}{*}{ İlkelilik iklim } & Dr. Öğr. Üyesi & 54 & 69,67 & 3,430 & 0,634 & - \\
\hline & Doç. Dr. & 23 & 58,43 & & & \\
\hline & Prof. Dr. & 9 & 49,22 & & & \\
\hline
\end{tabular}

${ }^{*} \mathrm{p}<0,05$

Akademisyenlerin, unvan değişkeni ile EİÖ, yardımsever ve ilkelilik iklimleri arasında istatistiksel olarak anlamlı fark bulunamamıştır $(p>0,05)$. Ancak egoist iklim alt boyutunda, unvan değişkenine göre gruplar arasında istatistiksel olarak anlamlı fark bulunmuştur $(\mathrm{p}<0,05)$. Akademisyenlerin egoist iklim alt boyut algılarına ilişkin farklılıkların kaynağını belirlemek amacıyla post hoc testlerinden games-howell testinden yararlanılmıştır. Buna göre; Doç. Dr. unvanına sahip akademisyenlerin, Prof. Dr. unvanına sahip akademisyenlere göre egosit iklim algılarının daha yüksek olduğu sonucuna ulaşılmıştır. 
Tablo 5. Akademisyenlerin Eleştirel Düşünme Düzeyleri İle Örgütsel Etik İklim ve Alt Boyutları Arasındaki Korelasyon Analizi

\begin{tabular}{|c|c|c|c|c|c|c|}
\hline & & KEDEÖ & Etik İklim & Egoist İklim & $\begin{array}{l}\text { Yardımsever } \\
\text { İklim }\end{array}$ & İlkelilik İklim \\
\hline \multirow{2}{*}{ KEDEÖ } & $\mathrm{r}$ & \multirow{2}{*}{1} &,$- 245^{* *}$ &,$- 299^{* * *}$ &,- 082 &,$- 289^{* *}$ \\
\hline & $\mathrm{p}$ & & ,005 & ,001 & ,355 & 001 \\
\hline \multirow{2}{*}{ Etik İklim } & $\mathrm{r}$ & & \multirow{2}{*}{1} & $826^{* *}$ & $895^{* *}$ &, $745^{* *}$ \\
\hline & $\mathrm{p}$ & & & ,000 & ,000 & ,000 \\
\hline \multirow{2}{*}{ Egoist İklim } & $\mathrm{r}$ & & & \multirow{2}{*}{1} &, $719^{* *}$ &, $415^{* *}$ \\
\hline & $\mathrm{p}$ & & & & 000 & ,000 \\
\hline \multirow{2}{*}{$\begin{array}{l}\text { Yardımsever } \\
\text { İklim }\end{array}$} & $\mathrm{r}$ & & & & \multirow{2}{*}{1} & $430^{* *}$ \\
\hline & $\mathrm{p}$ & & & & & ,000 \\
\hline \multirow{2}{*}{$\begin{array}{l}\text { İlkelilik } \\
\text { İklim }\end{array}$} & $\mathrm{r}$ & & & & & \multirow{2}{*}{1} \\
\hline & $\mathrm{p}$ & & & & & \\
\hline${ }^{*} \mathrm{p}<0,05$ & & & & & & \\
\hline${ }^{* *} \mathrm{p}<0,01$ & & & & & & \\
\hline
\end{tabular}

KEDEÖ ile yardımsever iklim, arasında anlamlı bir ilişki bulunamamıştır $(p>0,05)$. Buna karşı1ık KEDEÖ ile etik iklim (r=-,245) KEDEÖ ile egoist iklim (r=-,299), KEDEÖ ile ilkelilik (r=,289) iklimleri arasında negatif yönde anlamlı bir ilişki olduğu belirlenmiştir. Diğer bir ifadeyle eleştirel düşünme düzeyleri artıkça örgütsel etik iklim düzeyleri düşmekte, etik iklim düzeyleri artıkça eleştirel düşünme düzeyleri düşmektedir, aralarında ters bir ilişki olduğu söylenebilir.

Etik iklim ile egoist iklimi $(r=, 826)$, etik iklim ile yardımsever iklimi $(r=, 895)$, etik iklim ile ilkelilik $\mathrm{r}=, 745)$ iklimi, egoist iklim ile yardımsever iklimi ( $\mathrm{r}=, 719)$, egoist iklim ile ilkelilik ( $\mathrm{r}=$ ,415), iklimi, yardımsever iklim ile ilkelilik $(\mathrm{r}=, 430)$, iklimleri alt boyutları arasında ise pozitif yönde olumlu bir ilişki olduğu belirlenmiştir. Diğer bir ifadeyle bir alt boyut azalırken diğeri de azalır, bir alt boyut artarken diğeri de artar yorumu yapılabilir.

\section{Tartışma, Sonuç ve Öneriler}

Araştırmaya katılan akademisyenlerin KEDEÖ’nin toplam puan üzerinden değerlendirilmesi incelendiğinde, orta düzeyde bir eleştirel düşünme eğilimine sahip oldukları görülmektedir (Tablo 2). Yapılan araştırma sonuçları, alan yazındaki (Mangena ve Chabeli, 2005; Korkmaz, 2009; Lee, 2004; Pithers ve Sodden, 1999; Akt. Paul vd. 1997; Özdemir, 2005; Akt. Gündoğdu, 2009; Saçlı ve Demirhan, 2011; Baydar, 2012; ve Şen, 2009; Akt. Polat, 2014: 94) yapılan diğer çalışmaların sonuçları ile benzerlik göstermektedir. Ayrıca araştırma sonucunda, yüksek düzeyde eleştirel düşünme eğilimine sahip akademisyenin olmaması dikkat çekicidir. Örneğin; Şahin, Çakmak ve Hacımustafaoğlu 2015 yılında “Akademisyenlerin eleştirel düşünme becerileri ve eleştirel düşünme becerileri hakkındaki görüşlerinin incelenmesi" başlıklı çalışmalarında akademisyenlerin KEDEÖ'den aldıkları toplam puanları 
değerlendirdiklerinde, yüksek düzeyde bir eleştirel düşünme eğilimde oldukları görülmektedir. Bu sonuç araştırmamız ile farklılık göstermektedir.

KEDEÖ alt boyutlar açısından incelendiğinde ise; doğruyu arama, açık fikirlilik, sistematiklik, kendine güven alt boyutlarının orta düzeyde eleştirel düşünme becerisine sahip iken, analitiklik ve meraklılık alt boyutlarında yüksek düzeyde eleştirel düşünme eğiliminde oldukları görülmektedir (Tablo 2).

Araştırmaya katılan akademisyenlerin yaş değişkeni ile KEDEÖ arasında elde edilen puanlar bakımından istatistiksel olarak anlamlı farklılık saptanmamıştır ( $>00,05)$ (Tablo 3). Adams, Stover ve Whitlow (1999), Gülveren (2007), Kürüm (2002), Leaver-Dunm vd. (2002), Çıkrıkçı' nın 1996 yılında yapmış oldukları araştırma sonuçlarında yaşın eleştirel düşünme düzeyi üzerinde herhangi bir etkisi bulunmadığı sonucuna varılmıştır (Gülle, 2015: 99). Bu çalışmalar araştırmamızla paralellik gösterirken, Leaver-Dunn vd. (2002)'nin yapmış oldukları çalışmaların da ise bu bulgunun aksine, yaş ile eleştirel düşünme düzeyi arasında pozitif yönde anlamlı bir ilişki bulunmuştur. Yaş arttıkça deneyimlerin zenginleşmesi nedeniyle eleştirel düşünme düzeyinin artması beklendiği halde, bu araştırma da yaş değişkenine özgü herhangi bir farklılık bulunamamıştır. Bunun nedeni; yaş gruplarının birbirine yakın olmasından kaynaklanabilir.

Araştırmaya katılan akademisyenlerin cinsiyet değişkeni ile KEDEÖ arasında elde edilen puanlar bakımından istatistiksel olarak anlamlı fark olmadığı görülmektedir $(\mathrm{p}>0,05)$ (Tablo 3). Kürüm (2002), Tokyürek (2001), Akar (2007), Durmuş (2012), Karanfil (2014), Öztürk (2006), Leaver-Dunn vd. (2002), Loken (2005), Saçlı ve Demirhan (2008) ve Korur (2014) beden eğitimi ve spor öğrencilerine yönelik yapmış olduğu çalışmalar ile Kawashima ve Shiomi (2007), Korkmaz (2009), Ekinci ve Aybek (2010), Narin (2009) ve Khandaghi vd. (2011) tarafından farklı bölümlerde eğitim gören öğrencilere yönelik yapmış oldukları çalışma sonuçlarında eleştirel düşünme ile cinsiyet arasında anlamlı bir farklılığın olmadığını sonucuna ulaşmışlardır. Bu durum çalışmamızla paralellik göstermektedir. Bu bulguların aksine bazı çalışmalarda cinsiyet ile eleştirel düşünme arasında anlamlı bir ilişki olan çalışmalar bulunmaktadır (Adams, Stover ve Whitlow,1999; Walsh ve Hardy, 1999; akt. Öztürk, 2006: 63). Eleştirel düşünme eğilimini öğrenebilen bir beceri olduğundan dolayı kadın ve erkekler benzer şekilde bu beceriyi öğrenebilir. Bu nedenle cinsiyetin eleştirel düşünme düzeyini etkilemediğini söylemek mümkündür. Benzer şekilde araştırmaya katılan akademisyenlerin medeni durum, unvan ve hizmet süresi gibi demografik değişkenler ile KEDEÖ arasında elde edilen puanlar bakımından istatistiksel olarak anlamlı farklılık bulunamamıştır $(p>0,05)$ (Tablo 3). Yani eleştirel düşünme eğilimi bu demografik faktörlerden etkilenmemektedir.

Akademisyenlerin etik iklim ölçeği ve alt boyutlarının ortalamalarına göre bağlı oldukları üniversitelerin etik iklimine biraz katıldıkları ve olumlu olarak algıladıkları söylenebilir. Yani araştırmaya katılan akademisyenlerin etik iklim algılarının orta düzeyde olduğunu görülmektedir (Tablo 2). Mert 2017 yılında yapmış olduğu çalışma sonuçları araştırmamızla paralellik göstermektedir. Çalıştıkları kurumun etik iklimini olumlu algılamalarının, aynı zamanda çalışanları örgüte olan bağlılığını arttırdığına yönelik çalışmalar bulunmaktadır (Akbaş, 2010; Başar, 2009; DeConinck 2011; Cullen vd. 2003; Eser, 2007; Eren ve Hayatoğlu, 2011; Ünal, 2012; Martin ve Cullen, 2006; Huang vd. 2012; Öğ̈̈t ve Kaplan, 2011; Valentine vd. 2002; Schminke vd. 2005; Okpara ve Wynn, 2008; Ünal, 2012; Akt. Demir, 2018). Örgütlerde etik bir iklimin oluşturulmasıyla birlikte, örgütteki üyelerin birbirlerine nasıl davranmaları gerektiğini açıkça ifade eder. Cullen vd. (2003) etik iklim algısının pozitif olduğu bir kurumda, kişilerin birbirlerine yardım ettiklerini, birbirlerine karşı daha hassas davrandığını, kararlar 
alınması aşamasında kurallar ve gerekli düzenlemelere uygun davrandıkları belirtilmiştir. Kurum içerisinde oluşturulan pozitif algılının kuruma ilişkin iyi bilgilerin ve olumlu davranışların yayılmasını ve hatta örgüte yönelik tehditlerden kurumun korunmasını sağlar. Bağlı oldukları örgütte kendilerine değer ve önem verildiğini hisseden akademisyenler bağlı oldukları kurum ile bütünleşirler ve kurumun amaçlarının gerçekleştirmesi amacıyla çalışırlar (Demir, 2018:10). Sonuç olarak, etik iklim algısının olumlu olması akademisyenlerin kuruma olan bağlılıklarını, kuruma duydukları güvenlerini, birbirleriyle olan ilişkilerini ve kurumun amaçlarını ve hedeflerini gerçekleştirme anlamında alınan kararlarını etkilediği söylenebilir.

Araştırmaya katılan akademisyenlerin, unvan değişkeni ile etik iklim ölçeği ve yardımsever, ilkelilik iklimlerine ait elde edilen puanlar incelendiğinde istatistiksel anlamlı fark bulunamamıştır ( $p>0,05)$ (Tablo 4). Ancak egoist iklim alt boyutunda, unvan değişkenine göre gruplar arasında istatistiksel olarak anlamlı fark bulunmuştur $(p<0,05)$. Akademisyenlerin egoist iklim alt boyut algılarına ilişkin farklılığın belirlenmesi için post hoc testlerinden gameshowell testinden yararlanılmıştır. Buna göre; Doç. Dr. unvanına sahip akademisyenlerin, Prof. Dr. unvanına sahip akademisyenlere göre egosit iklim algılarının daha yüksek olduğu görülmektedir.

Araştırmaya katılan akademisyenlerin eleştirel düşünme düzeyleri ile örgütsel etik iklim ve alt boyutları arasındaki korelasyon analizi tablo 5'de verilmiştir. KEDEÖ ile etik iklim ve alt boyutları arasındaki korelasyon katsayıları incelendiğinde, bu alandaki korelasyon katsayılarının genel olarak istatiksel düzeyde anlamlı olduğu görülmektedir $(p<0,05)($ Tablo 5). Ancak KEDEÖ ile yardımsever iklim, arasında anlamlı bir ilişki bulunamamıştır $(p>0,05)$ (Tablo 5).

KEDEÖ ile etik iklim (r=-,245) KEDEÖ ile egoist iklim (r=-,299), KEDEÖ ile yardımsever iklim(r=-,082), KEDEÖ ile ilkelilik (r=-,289) iklimleri arasında negatif yönde anlamlı bir ilişki olduğu belirlenmiştir. Yani, eleştirel düşünme düzeyleri artıkça örgütsel etik iklim algıları düşmekte, etik iklim algıları artıkça eleştirel düşünme düzeyleri düşmektedir, araların ters yönde bir ilişki olduğu görülmektedir (Tablo 5). Sonuç olarak; araştırmaya katılan akademisyenlerin eleştirel düşünme düzeyleri yüksek olduğunda, örgütün etik iklimini düşük olarak algıladıklarını ve etik iklim algıları yüksek olduğunda ise; eleştirel düşünme becerilerinin düşük olduğunu sonucuna ulaşılmıştır. KEDEÖ ile etik iklim arasında bir ilişki olup olmadığını belirlemek amacıyla yapmış olduğumuz araştırma aralarında güçlü ve ters yönde bir ilişki olduğunu ortaya koymuştur.

Araştırma sonuçları, eleştirel düşünme konusuna daha fazla önem verilmesi gerektiğini göstermektedir. Eğitim programları içerisinde eleştirel düşünmeye daha çok yer verilmesi, eleştirel düşünmenin öğretilmesi, bireylerin farklı görüşlere, fikirlere açı olmaları veya düşüncelerini özgürce ifade edebilmeleri açısından önemli olduğu söylenebilir. Bilimsel üretim ve verimlilik için akademisyenlerin çalışma ortamında yaratılacak olan etik iklim büyük önem taşımaktadır. Etik iklim algılarının yükselmesi, akademisyenlerin kuruma olan bağlılıklarını, kuruma duydukları güvenlerini, birbirleriyle olan ilişkilerini ve kurum amaçlarını gerçekleştirme yönündeki çalışmaların etkililiğini arttırabilir. Gelecekte araştırmacılar eleştirel düşünme ve etik iklim konularını farklı konular ilişkilendirilerek veya farklı örneklemler grupları üzerinde araştırmanın sınırlılıkları değiştirilerek farklı çalışmalar yapabilir. Ayrıca eleştirel düşünmenin alt boyutları ile etik iklimin alt boyutlarının ilişkilendirilmesini kapsayan daha kapsamlı çalışmalar da yapılabilir. 


\section{Kaynakça}

Akar, C. (2007). Illköğretim Öğrencilerinde Eleştirel Düşünme Becerileri. (Doktora Tezi). Ankara: Gazi Üniversitesi Eğitim Bilimleri Enstitüsü.

Akbaş, T. (2010). Örgütsel Etik İklimin Örgütsel Bă̆lıllk Üzerindeki Etkisi: Mobilya Sanayi Büyük Ölçekli İşletmelerinde Görgül Bir Araştırma. KMÜ Sosyal ve Ekonomik Araştırmalar Dergisi 12 (19): 121-137.

Akbıyık, C. ve Seferoğlu, S.S. (2006). Eleştirel Düşünme Eğilimleri ve Akademik Başarı. Çukurova Üniversitesi Ĕ̆itim Fakültesi Dergisi. 3(32):91.

Balc1, F. (2015). Yönetici Hemşirelerin Eleştirel Düşünme Eğilimleri ve Bir Araştırma. (Yüksek Lisans Tezi). İstanbul: İstanbul Üniversitesi Sosyal Bilimler Enstitüsü.

Başar, H. (2013). Nasıl Düşünelim? Ankara: Pegem Akademi Yayıncılık.

Bilgen, A. (2014). Çalışanların Etik Liderlik Ve Etik İklim Algılamalarının Örgütsel Bă̆lılıklarına Etkisi: Özel Ve Kamu Sektöründe Karşılaştırmalı Bir Uygulama. (Yüksek Lisans Tezi). İstanbul: Bahçeşehir Üniversitesi Sosyal Bilimler Enstitüsü.

Bulut, S., Ertem, G., Sevil, Ü.,, (2009). Hemşirelik Öğrencilerinin Eleştirel Düşünme Düzeylerinin İncelenmesi. Dokuz Eylül Üniversitesi Hemşirelik Yüksekokulu Elektronik Dergisi. 2(2): 28.

Burkhart, L. M. (2006). Thinking Critically About Critical Thinking: Developing Thinking Skills Among High School Students. California: Claremont Graduate University.

Cullen, J.B., K.P. Parboteetah, and B. Victor, (2003). The Effects of Ethical Climates on Organizational Commitment: A Two-Study Analysis. Journal of Ethics 46: 127-141.

Demir, S. (2018). Etik İklim ve Okuldan Ayrılma Niyeti Arasındaki İlişki: Örgütsel Bağlılığın Aracılık Rolü. Hacettepe Üniversitesi Eğitim Fakültesi Dergisi. 10(201):10.

Dönertaş, C. F. (2008). Etik iklimin kuruma güven üzerindeki etkisi. (Yüksek lisans Tezi). İstanbul: Marmara Üniversitesi Sosyal Bilimler Enstitüsü.

Durmuş. M. (2012). Hemşirelik Son Sınıf Öğrencilerinin Eleştirel Düşünme Düzeylerinin Belirlenmesi. (Yayımlanmamış Yüksek Lisans Tezi). Ankara: Gazi Üniversitesi Sağlık Bilimleri Enstitüsü.

Erdirençelebi, M. ve Filizöz, B. (2016). Mobbingin Etik İklim ve Çalışanların İşten Ayrılma Niyeti Üzerine Etkileri. Selçuk Üniversitesi Sosyal Bilimler Enstitüsü Dergisi, (35): 127-139.

Eser, G. (2007). Etik İklim ve Yöneticiye Güvenin Örgütsel Bă̆gllı̆̆a Etkisi. (Yayınlanmamış Yüksek Lisans Tezi). İstanbul: Marmara Üniversitesi Sosyal Bilimler Enstitüsü.

Ekinci, Ö. ve Aybek, B. (2010). Öğretmen Adaylarının Empatik ve Eleştirel Düşünme Eğilimlerinin İncelenmesi. İlköğretim Online Dergisi.9(2): 816-827.

Gurbetoğlu, A. (2018). Bilimsel Araştırma Yöntemleri Ders Notları.

Gülle, M. (2015). Beden Eğitimi ve Spor Yüksekokulu Öğrencilerin Bölümlerine Göre Eleştirel Düşünme ve Empati Kurma Düzeylerinin İncelenmesi. (Doktora Tezi). Sakarya: Sakarya Üniversitesi Eğitim Bilimleri Enstitüsü. 
Gündoğdu, H. (2009). Eleştirel Düşünme ve Eleştirel Düşünme Öğretimine Dair Bazı Yanılgilar. Sosyal Bilimler Dergisi. 7(1): 57-74.

Karanfil, A.Y. (2014). Beden Eğitimi ve Spor Yüksekokulu Öğrencilerinin Eleştirel Düşünme Düzeylerinin Çeşitli Demografik Faktörler Açısından İncelenmesi. (Yüksek Lisans Tezi). Muğla: Muğla Sıtkı Koçman Üniversitesi Sağlik Bilimleri Enstitüsü.

Kaya, H. (1997). Üniversite Öğrencilerinde Eleştirel Akıl Yürütme Gücü.(Doktora Tezi) İstanbul: İstanbul Üniversitesi Sağlık Bilimleri Enstitüsü.

Kawashima, N., \& Shiomi, K. (2007). Factors of The Thinking Disposition of Japanese High School Students. Social Behavior and Personality: an International Journal. 35(2):187-194.

Khandaghi, M. A., Pakmehr, H., \& Amiri, E. (2011). The Status Of College Students Critical Thinking Disposition in Humanities. Procedia-Social and Behavioral Sciences 15.

Korkmaz, Ö. (2009). Öğretmenlerin Eleştirel Düşünme Eğilim ve Düzeyleri. Ahi Evran Üniversitesi Kırşehir Ĕ̆itim Fakültesi Dergisi. 10(1): 1-13.

Korur, E.N. (2014). Beden Eğitimi Öğretmeni Adaylarının Eleştirel Düşünme ve Empatik Ĕ̆ilimleri. (Doktora tezi). Trabzon: Karadeniz Teknik Üniversitesi Eğitim Bilimleri Enstitüsü.

Kökdemir, D. (2003a). Eleştirel Düşünme. www.baskent.edu.tr/elyad

Kökdemir, D. (2003b). Eleştirel Düşünme ve Bilim Eğitimi. Pivolka. 2(4): 3-5.

Kutlu, M.O. ve Schreglmann, S.(2011). Üniversitelerde Görev Yapan Akademisyenlerin Eleştirel Düşünme Eğilimlerinin Fakülte ve Unvanlarına Göre İncelenmesi. Çukurova Üniversitesi Eğitim Fakültesi Dergisi. 3(40): 116-121.

Kürüm, D. (2002). Öğretmen Adaylarının Eleştirel Düşünme Gücü. (Yüksek Lisans Tezi). Eskişehir: Anadolu Üniversitesi Eğitim Bilimleri Enstitüsü.

Leaver-Dunn, D., Harrelson, G. L., Martin, M., \& Wyatt, T. (2002). Critical-Thinking Predisposition Among Undergraduate Athletic Training Students. Journal of Athletic Training. 37(4):147.

Loken, M. L. (2005). Critical Thinking Abilities of Undergraduate Entry-Level Athletic Training Students. (Unpublished Doctoral Dissertation). The University of South Dakota, USA.

McBride, R. E. (1992). Critical Thinking - An Overview with İmplications for Physical Education. Journal of Teaching in Physical Education, 11, (2), 112-125.

McBride, R. E. \& Cleland, F. (1998). Critical Thinking In Physical Education: Putting the Theory Where it Belongs: In The Gymnasium. Journal of Physical Education, Recreation E Dance, 69(7), 42-46.

Mert, N. (2017). Yönetici ve Yönetici Olmayan Hemşirelerin Etik İklim Alg̨larının Karşılaştırılması. (Yüksek Lisans Tezi). İstanbul: İstanbul Medipol Üniversitesi Sağlık Bilimleri Enstitüsü.

Narin, N. (2009). İlköğretim İkinci Kademe Sosyal Bilgiler Öğretmenlerinin Eleştirel Düşünme Becerilerinin İncelenmesi. (Yüksek Lisans Tezi). Adana: Çukurova Üniversitesi Sosyal Bilimler Enstitüsü.

Öztürk, N. (2006). Hemşirelik Öğrencilerinin Eleştirel Düşünme Düzeyleri ve Eleştirel Düşünmeyi Etkileyen Faktörler. (Yüksek Lisans Tezi). Sivas: Cumhuriyet Üniversitesi Sağlık Bilimleri Enstitüsü. 
Öztürk, N., ve Ulusoy, H. (2008). Lisans ve Yüksek Lisans Hemşirelik Öğrencilerinin Eleştirel Düşünme Düzeyleri ve Eleştirel Düşünmeyi Etkileyen Faktörler. Maltepe Üniversitesi Hemşirelik Bilim ve Sanatı Dergisi.1(1): 6.

Polat, M. (2017). Sınıf Öğretmenlerinin Eleştirel Düşünme Ĕ̆gilimleri İle Yaratıcılık Düzeylerinin Bazı Değişkenlere Göre İncelenmesi. (Yayınlanmış Yüksek Lisans Tezi). Adıyaman: Adıyaman Üniversitesi Sosyal Bilimler Enstitüsü.

Polat, S. (2014). Eleştirel Düşünme Becerisi Öğretiminin Çok Yönlü İncelenmesi. (Doktora Tezi). Konya: Eğitim Bilimleri Enstitüsü.

Robey, J. A. (2002). The Impact of Belief Bias and Epistemological Beliefs on Critical Thinking in Preservice Teachers. (Doctoral Dissertation). USA: The University of Minnesota.

Rucks, M. G. (2001). The Effects of Academic Achievement on the Critical Thinking Skills of College Students. (Doctoral Dissertation). Michigan: Wayne State University.

Saçlı, F. (2013). Yaratıcı Drama Ĕ̆itiminin Aday Beden Eğitimi Öğretmenlerinin Eleştirel Düşünme Becerileri ve Eğilimleri Üzerine Etkisi. (Doktora Tezi ). Ankara: Hacettepe Üniversitesi Sağlık Bilimleri Enstitüsü Spor Bilimleri ve Teknolojisi Programı.

Saçlı, F. ve Demirhan, G. (2008). Beden Eğitimi ve Spor Öğretmenliği Programında Öğrenim Gören Öğrencilerin Eleştirel Düşünme Düzeylerinin Saptanması ve Karşılaştırılması. Spor Bilimleri Dergisi.19(2): 92-110.

Şahin B. ve Dündar T. (2011). Sağlık Sektöründe Etik İklim ve Yıldırma (Mobbıng) Davranışları Arasındaki İlişkinin İncelenmesi. Ankara Üniversitesi Sosyal Bilimler Dergisi. 66(1):130-159.

Şahin, Ç., Çakmak, N. ve Hacımustafaoğlu, M. (2015). Akademisyenlerin Eleştirel Düşünme Becerilerinin ve Eleştirel Düşünme Becerileri Hakkındaki Görüşlerinin İncelenmesi. İnönü Üniversitesi Eğitim Fakültesi Dergisi.16 (2): 51-66.

Tiryaki, Ş.H, ve Bahçecik, N. (2014). Üniversite Hastanesinde Çalışan Yönetici Hemşire ve Hemşirelerin Kurumsal İklimi Algılayışları. Hacettepe Üniversitesi Hemşirelik Fakültesi Dergisi, 1-5.

Tishman, S., Perkins, D.N. (1995). Critical Thinking and Physical Education. Journal of Physical Education, Recreation \& Dance, 66 (6), 24-31.

Tokyürek, T. (2001). Öğretmen Tutumlarının Öğrencilerin Eleştirel Düşünme Becerilerine Etkisi.(Yüksek Lisans Tezi). Sakarya: Sakarya Üniversitesi Sosyal Bilimler Enstitüsü.

Wienerman, I. (1997). Creativity in the Classroom: An Examination of Student Teacher Personality and Perceptions of the Classroom Setting. (Doctoral Dissertation). Newyork: Fordham University.

Yildiz, K., Güzel, P., \& Zerengök, D. (2019). A theoretical approach to the use of information and communication technologies in Physical Education. SPORT TK: Revista Euroamericana de Ciencias del Deporte, 8, 2, 81-88. https://doi.org/10.6018/sportk.391801.

Yıldız, K., Kurnaz, D., \& Kırık, A. M. (2020). Nomofobi, Netlessfobi ve Gelişmeleri Kaçırma Korkusu: Sporcu Genç Yetişkinler Üzerine Bir Araştırma. Celal Bayar Üniversitesi Sosyal Bilimler Dergisi, 18(Özel Sayı), 321-338. https://doi.org/10.18026/cbayarsos.669601. 